\title{
New material of a derived ornithomimosaur from the Upper Cretaceous Nemegt Formation of Mongolia
}

\author{
Robert Bronowicz \\ Acta Palaeontologica Polonica 56 (3), 2011: 477-488 doi: http://dx.doi.org/10.4202/app.2009.1123
}

New material of an ornithomimid from the Late Cretaceous deposits of Tsagan Khushu (Gobi Desert, Mongolia) is described. The material includes a partial axial skeleton, and hind and forelimb elements. The specimen is similar to Anserimimus planinychus from nearby Bugin Tsav locality in having ventrally flat, long, almost straight manual unguals. The new specimen differs from A. planinychus in the length of the penultimate manual phalanx II-2, which is only slightly shorter than $\mathrm{Ph}$ III-3, in a considerably lesser alae of the manual unguals, and in the height/width ratio of the proximal articular surfaces. The material suggests presence of third, hitherto unknown ornithomimid from the Nemegt Formation.

Key words: Dinosauria, Ornithomimidae, Anserimimus, Cretaceous, Nemegt, Mongolia.

Robert Bronowicz [r.bronowicz@uw.edu.pl], Zakład Paleontologii, Wydział Geologii, Uniwersytet Warszawski, Al. Żwirki i Wigury 93, PL 02-089 Warszawa, Poland.

This is an open-access article distributed under the terms of the Creative Commons Attribution License (for details please see creativecommons.org), which permits unrestricted use, distribution, and reproduction in any medium, provided the original author and source are credited. 